\title{
The Online Purchasing Contract Done by Students of Faculty of Law in Lampung University
}

\author{
Kasmawati $^{1}$, Dewi Septiana ${ }^{2}$ \\ \{kasmawati.kukuh@gmail.com ${ }^{1}$,dewi.septian@fh.unila.ac.id²\} \\ Faculty of Law, Universitas Lampung, Bandar Lampung, Indonesia
}

\begin{abstract}
Selling and buying are activities commonly done by public both in urban and rural areas. Along with age development, purchasing goods must not necessarily be done directly, but can be done with online purchasing, by using internet media. Online selling and buying are activities where seller and buyer must not necessarily meet to do negotiation, transaction, and communication, and it is not separated from Article 1320 of Civil Code (KUHPerdata). Many students of faculty of law use online media to chat, make phone call, to do SMS, to use Facebook, Instagram, etc. Therefore, the author conducted a study with problems on how did the implementation of online purchasing done by students of faculty of law and how did the legal effect of this online purchasing. This was a normative empirical and descriptive research by using sociological jurisdiction approach. Primary data were collected by field study with interviews to 50 students of faculty of law who conducted online purchasing. The research result with samples of 50 students of faculty of law who conducted online purchasing showed that this selling and buying transaction had been done according to the requirements for a valid contract from Article 1320 of Civil Code (KUHPerdata). The requirements were that seller and buyer must be polite, communication was done by using good Wi-Fi and hotspot network in campus environment, by using pictures in internet, and students selected the pictures that they liked, they stated their agreements to do purchasing by filling name, phone number, address, and then students did the payment to a referred bank by the seller. After these processes finished, the student would send transfer evidence to the seller, and then the seller would send the desired goods. The legal effect of online purchasing done by the students was that an agreement that the purchaser had the right upon the goods with any risk that the goods might be received beyond expectation. $50 \%$ samples who did online purchasing were not satisfied because the received goods were beyond expectation.
\end{abstract}

Keywords: agreement; selling and buying; online

\section{Introduction}

The increase on social and economic activity with the constellation of world society has entered into an information-oriented society. The systematic progress of information and technology have been used in many sectors of life, ranging from trade or business (electronic commerce or e-commerce), education (electronic education), health (tele-medicine), telekarya, transportation, industry, tourism, and environment to the entertainment sector. Information technology includes systems that collect, store, process, produce and send information from industry to society effectively and quickly. Information Technology provides numerous benefits and offers an appealing promise for life in the digital age like today, by using the 
sophistication of information technology, we can do many things in minutes. Information technology can really help us do the work and solve it more effectively and efficiently. The increasingly rapid development of Information and Communication Technology in Indonesia leads to technological convergence which has an impact on the paradigm shift in the telecommunications industry and business.

The paradigm shift includes technology shifts, changes in business structure and patterns, and their effects on people's lives. Article 1 number 2 of Law of the Republic of Indonesia No. 11 Of 2008 Concerning Electronic Information and Transactions hereinafter referred to as ITE Law, define electronic transactions as a legal act that is committed by the use of Computers, Computer networks, and/or other electronic media. The next word is an online word which is often translated in Indonesian as a 'dalam jaringan' or better known as the abbreviation 'daring'. Online refers to when computer established an Internet connection, if our computer or mobile phone is online then we can access the internet. With this access, we can establish communication (both verbal and nonverbal) only online with various nations and countries throughout the world. Online can also be used as an adjective to describe activity performed while on the Internet, such as online shopping.

The internet provides the opportunity for a company to develop or supporting its business and reach geographically dispersed customers. It happened in the law faculty environment, where many students made buying and selling transactions through Wi-Fi within the faculty of law. Students make purchases for the needs in the field of fashion and beauty. At first the purchase of fashion and beauty products was done with conventional methods but later changed using an online shop application (electronic commerce). Based on the background above, the writer is interested in writing with the title Online Purchase Agreement Made by University of Lampung Faculty of Law Students.

\section{Research Results and Discussion}

\subsection{Implementation of Online Purchase Agreements Made by Faculty of Law students}

Article 1313 of the Indonesian Civil Code states that the meaning of an agreement is an act pursuant to which one or more individuals bind themselves to one another. According to Abdulkadir Muhammad, an agreement is an agreement by which two or more parties commit themselves to carry out a material thing in the field of assets. According to Subekti, an agreement is an event where someone promises to a person or where two people promise one another to do something, then from this event, an engagement relationship arises. The definition of electronic contracts is explained in Article 1 number 17 of the ITE Law that Electronic Contract is an agreement of parties entered into by means of Electronic Systems. Business entity who offering goods or services must provide information about the terms of the contract, complete and correct product contents of goods or services electronically.

We can see elements from online shopping are trade contracts, electronic media, physical presence is not needed, contracts in public networks, and the systems are open. Information technology has offered various facilities such as speed of data and information access, problem solving and work automation and so on. Intensive and extensive use of computers, internet, cell phones and ATMs has overcome the limitations of space and time. Buying and selling activities are part of the agreement activities. Buying and selling does not have to be 
done directly, that is, face to face, but can be done through online media using the internet. The use of internet media can be done with Facebook, Instagram, WhatsApp, and others.

The principles adopted in buying and selling online adhere to the Indonesian Civil Code, especially in Article 1320 of the Civil Code, in order to be valid, an agreement must satisfy the following four conditions:

1. There must be consent of the individuals who are bound thereby The seller offers the goods to the buyer and the buyer agrees to buy it. The seller sends the purchase format through internet media. In general, students of the Faculty of Law use the social media like Facebook, Instagram, and WhatsApp in carrying out buying and selling transactions. In the implementation of this buying and selling, Buyers, in this case, Law students make purchases by agreeing to their purchases, then an agreement automatically occurs.

2. There must be capacity to enter into an obligation According to the Indonesian Civil Code, the competent criteria are 21 years old. Students who buy and sell online are 21 years old, and all of the samples we used are 21 years old.

3. There must be a specific subject matter Certain objects are goods that are traded and their types are determined. Products offered online in the form of images or photos as well as with product specifications. Law students more than $75 \%$ buy products in Fashion and beauty.

4. There must be a permitted cause

5. It does not conflict with law, decency, and order. In buying and selling online, it must be ensured that transactions conducted by law students are carried out in good faith with the seller.

The ITE Law also regulates the terms and conditions for online trading transactions, namely:

1. Information Technology and Electronic Transaction utilization shall be implemented under the principles of legal certainty, benefit, prudence, good faith, and freedom to choose technology or technology neutrality.

2. Any Business Entity offering products through the Electronic System must provide complete and accurate information relating to the contract terms, manufacturers, and products offered

3. Parties that conduct Electronic Transactions must be in good faith in making interaction and/or exchange of Electronic Information and/or Electronic Documents during the transactions.

4. Provisions on the time of sending and receiving information and/or electronic transactions.

The terms of online sale and purchase are seen that when there is a transaction or agreement between the seller and the buyer, the buyer is a student of the Faculty of Law when an agreement occurs and before payment occurs, the seller will ask for the cost of shipping the goods. What shipping costs will be offered will use, when the buyer agrees it will be combined with the cost of purchasing goods that have been ordered. This is by the provisions contained in the Civil Code and the ITE Law.

\section{Legal Consequences of Online Purchases Conducted by Law Faculty Students}

Legal consequences are consequences that arise due to events, actions, and legal relationships. A legal effect can arise because of acts or actions that are intentionally carried out in order to arise the desired consequences in accordance with legal regulations. Article 
1320 of Indonesian Civil Code is a benchmark of the validity of an agreement, both in terms of subjective and objective conditions. An agreement that meets both subjective and objective conditions applies as binding to the parties to the agreement as the binding force of the law. Non-fulfillment of terms, both subjective or objectives, have impacts on the binding power of an agreement.

Subekti explained that an agreement that did not meet the subjective requirements could be requested for cancellation by one of the parties. An agreement that does not fulfill the objective requirements may cause an agreement to be treated as non-exist. Thus making the agreement should pay attention to the subjective and objective conditions, so that the rights and obligations of the parties contained in the agreement have legal binding force. In the event of such online trading, rights and obligations arise. The buyer's right is to receive the goods they bought in accordance with what they wants, while the obligation of a buyer under the contract of sale is to pay the price for the goods delivered. While the seller's right is to receive payment agreed with the buyer, the obligation of the seller is delivering the goods and transfer the property in the goods to the buyer, which for its part agrees to pay the price for the goods and take delivery of them.

Law faculty of Lampung University students on average, order goods via the internet through online shopping websites such as Tokopedia, Shopee, belibeli.com and some buy through Facebook and Instagram. In the case of clothing purchases, online shoppers do not have the ability to physically inspect or try on the items being considered for purchase, that's why the average is expressed dissatisfaction because the picture that look good and display properly and the original items are not suitable. Also, when they have received the goods ordered, most sizes do not fit, and goods that have been ordered cannot be returned.

\section{Conclusion}

Based on the results of the research described, it can be concluded that:

1. On-line purchases made by students of the Faculty of Law are in accordance with the provisions of the law contained in Article 1320 of the Indonesian Civil Code, which is first, agreed, by agreeing to the conditions that have been determined then automatically an agreement occurs, second, competent, the capacity to enter into an obligation that students have aged 21 years, third, specific subject matter that is the purchase of fashion and cosmetics, fourth, permitted cause, the purchase is not contrary to the law, decency and order.

2. The legal consequences of online purchases made by the student are appropriate because there have been rights and obligations where the seller provides the goods and the buyer pays the amount of money specified in the payment

\section{References}

[1] Alsadan, Meshal, Ashraf Metwally, Anna Ali, Amr Jamal, Mohamed Khalifa, and Mowafa Househ. "View of Health Information Technology (HIT) in Arab Countries: A Systematic Review Study on HIT Progress." Journal of Health Informatics in

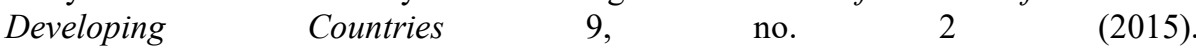
https://jhidc.org/index.php/jhidc/article/view/138/187.

[2] Bagus Wicaksono, Dimas. "Perlindungan Hukum Terhadap Konsumen Go-Jek (Layanan Transportasi Dengan Aplikasi Online) Dalam Perjanjian Aplikasi Go-Jek 
Berdasarkan Pasal 1320 KUHPerdata." JUSTITIA JURNAL HUKUM 1, no. 2 (October 29, 2017). https://doi.org/10.30651/justitia.v1i2.1164.

[3] Dewi, Sri Anggraini Kusuma. "Perjanjian Jual Beli Barang Melalui Elektronik Commerce (E-Com) | Jurnal Ilmiah Teknologi Informasi Asia.” Jurnal Ilmiah Teknologi Informasi Asia 9, no. 2 (2015). https://www.jurnal.stmikasia.ac.id/index.php/jitika/article/view/102.

[4] Khan, W.Z., M.H. Rehman, H.M. Zangoti, M.K. Afal, N. Armi, and K. Salah. "Industrial Internet of Things: Recent Advances, Enabling Technologies, and Open Challenges." Computers and Electrical Engineering 81 (2020): 1-13. https://etarjome.com/storage/panel/fileuploads/2020-02-03/1580712597 E14283-etarjome.pdf.

[5] Low, Janie. "INTERNET BANKING-BENEFITS AND CHALLENGES IN AN EMERGING ECONOMY Want More Papers like This? INTERNET BANKINGBENEFITS AND CHALLENGES IN AN EMERGING ECONOMY." International Journal of Research in Business Management (IJRBM). Vol. 1, 2013.

[6] Luh, Oleh, and Nila Winarni. "ASAS ITIKAD BAIK SEBAGAI UPAYA PERLINDUNGAN KONSUMEN DALAM PERJANJIAN PEMBIAYAAN.” Jurnal Hukum Undiknas. Vol. 2, August $1, \quad 2015$. http://journal.undiknas.ac.id/index.php/hukum/article/view/34.

[7] Sari, Novi Ratna. "KOMPARASI SYARAT SAH NYA PERJANJIAN MENURUT KITAB UNDANG-UNDANG HUKUM PERDATA DAN HUKUM ISLAM | Sari | Jurnal Repertorium." Repertorium 4, no. 2 (2017). https://jurnal.uns.ac.id/repertorium/article/view/18284.

[8] Setyawati, Desy Ary, Dahlan Ali, and M. Nur Rasyid. "Perlindungan Bagi Hak Konsumen Dan Tanggung Jawab Pelaku Usaha Dalam Perjanjian Transaksi Elektronik." Syiah Kuala Law Journal 1, no. 3 (December 14, 2017): 46-64. https://doi.org/10.24815/sklj.v1i3.9638.

[9] Wiguna, I Made Bayu, and I Dewa Made Suartha. "TINJAUAN YURIDIS TERHADAP PENGATURAN MEMORANDUM OF UNDERSTANDING DALAM KITAB UNDANG-UNDANG HUKUM PERDATA | Kertha Semaya: Journal Ilmu Hukum." Kertha Semaya 5, no. 2 (2017). https://ocs.unud.ac.id/index.php/kerthasemaya/article/view/20937.

[10] Winarno, Wahyu Agus. "SEBUAH KAJIAN PADA UNDANG-UNDANG INFORMASI DAN TRANSAKSI ELEKTRONIK (UU ITE) | Jurnal Ekonomi Akuntansi Dan Manajemen.” Jurnal Ekonomi Akuntasi Dan Manajemen 10, no. 1 (2011). http://jurnal.unej.ac.id/index.php/JEAM/article/view/1207. 